\title{
Hubungan Lama Duduk Terhadap Keluhan Nyeri Punggung Bawah
}

\author{
Ruth O. Hutasuhut, ${ }^{1}$ Fransiska Lintong, ${ }^{2}$ Jimmy F. Rumampuk ${ }^{2}$
}

\author{
${ }^{1}$ Program Studi Pendidikan Dokter Fakultas Kedokteran Universitas Sam Ratulangi \\ Manado, Indonesia \\ ${ }^{2}$ Bagian Fisika Fakultas Kedokteran Universitas Sam Ratulangi Manado, Indonesia \\ Email: ruthocthalia@gmail.com
}

\begin{abstract}
Low back pain is a musculoskeletal disorder that is often found in society. Low Back Pain can cause quality of life to deteriorate and inhibits certain activities. Certain influential factors such as age, gender, Body Mass Index, stress, length of sitting, and posture when doing work. Low Back Pain is a risk to medical students. Purpose of this study was to determine the relationship between sitting time and complaints of low back pain in students of the Faculty of Medicine, Sam Ratulangi University. The research method used is an observational analytic method with a cross-sectional design. Data were collected using a questionnaire and then analyzed using the Pearson Chi-square test. The results showed a $\mathrm{p}$ value ( $\mathrm{p}<0.001)$ between the length of sitting and complaints of low back pain, with a sitting time of 5- 8 hours. In conclusion, there is a significant relationship between sitting time and complaints of low back pain in students of the Faculty of Medicine, Sam Ratulangi University. Keywords: Low Back Pain, prolonged sitting, medical students
\end{abstract}

\begin{abstract}
Abstrak: Nyeri Punggung Bawah (NPB) merupakan gangguan muskuloskeletal yang sering ditemukan dalam masyarakat. NPB dapat menyebabkan kualitas hidup memburuk dan menghambat aktivitas tertentu. Beberapa faktor tertentu yang berpengaruh seperti umur, jenis kelamin, Indeks Massa Tubuh, stres, lama duduk, dan sikap tubuh ketika melakukan pekerjaan. NPB berisiko terjadi pada mahasiswa kedokteran. Tujuan dari penelitian ini adalah untuk mengetahui hubungan lama duduk terhadap keluhan nyeri punggung bawah pada mahasiswa Fakultas Kedokteran Universitas Sam Ratulangi. Metode penelitian yang digunakan adalah metode analitik observasional dengan desain potong lintang. Data dikumpulkan menggunakan kuisioner kemudian di analisis menggunakan uji statistik Pearson Chi-square. Hasil penelitian menunjukan $\mathrm{p}$ value $(\mathrm{p}<0,001)$ antara lama duduk dan keluhan nyeri punggung bawah, dengan lama duduk 5- 8 jam. Sebagai simpulan, terdapat hubungan bermakna antara lama duduk terhadap keluhan nyeri punggung bawah pada mahasiswa Fakultas Kedokteran Universitas Sam Ratulangi.
\end{abstract}

Kata Kunci : Nyeri Punggung Bawah, lama duduk, mahasiswa kedokteran

\section{PENDAHULUAN}

Posisi duduk yang lama dengan postur yang tidak nyaman dapat menyebabkan gangguan muskuloskeletal sehingga mengubah posisi duduk secara teratur ketika duduk yang lama disarankan untuk dapat mengurangi risiko nyeri punggung bawah, rasa tidak nyaman pada daerah lumbar, kelelahan otot punggung dan kelelahan mental fisik akibat kerja. ${ }^{1}$ Beberapa penelitian menunjukkan intensitas tertinggi gangguan muskuloskeletal terkait posisi duduk terjadi pada pekerja dengan durasi duduk yang lama. ${ }^{1-2}$ Mahasiswa dan aktivitas perkuliahan maupun pembelajaran memungkinkan setiap individunya untuk duduk dalam waktu yang lama, khususnya mahasiswa Fakultas Kedokteran Universitas Sam Ratulangi yang sejak bulan Maret 2020 melakukan pembelajaran jarak jauh akibat dari pandemi COVID-19 sehingga 
membutuhkan waktu duduk yang cukup lama untuk duduk kuliah menggunakan laptop atau gadget lainnya. Namun, sebagian besar masyarakat masih belum memberi perhatian lebih terkait menerapkan posisi duduk yang benar meskipun hal itu kedepannya dapat berdampak pada kesehatan masyarakat. $^{3}$

Keluhan paling sering ditemukan akibat durasi duduk yang lama dan posisi duduk yang salah adalah Nyeri Punggung Bawah (NPB). Menurut Global Burden of Disease Study 2017, angka kejadian penderita NPB pada tahun 1990 sebesar 377,5 juta dan meningkat menjadi 577 juta di tahun 2017. Pada tahun 2017, prevalensi NPB tertinggi adalah Amerika Latin Selatan $(13,47 \%)$, diikuti oleh Asia Pasifik $(13,16 \%)$, sedangkan terendah adalah Asia Timur $(3,92 \%)$, diikuti oleh Amerika Latin Tengah (5,62\%). Angka kejadian penderita NPB tertinggi adalah Asia Selatan (96,3 juta), diikuti oleh Asia Timur (67,7 juta), sedangkan angka kejadian penderita NPB terendah adalah Oseania ( 0,7 juta), disusul Karibia (2,7 juta). ${ }^{4}$ Di Indonesia belum ditemukan data epidemiologi mengenai NPB.

Duduk dalam waktu yang lama tanpa ada istirahat bisa berdampak pada struktur tulang belakang akibat proses biomekanika yang terjadi pada tulang belakang. ${ }^{5}$ Pada saat duduk, tekanan pada diskus intervertebralis lebih besar dua kali dibandingkan pada posisi berdiri. Hal ini dapat menyebabkan kualitas hidup seseorang memburuk karena nyeri yang timbul jika dibiarkan. Keluhan pada masing-masing orang bervariasi karena persepsi nyeri seseorang berbeda akibat adaptasi neuromuskuler pada jaringan lunak tulang belakang, dari nyeri ringan sampai nyeri berat yang membutuhkan intervensi khusus.

Penelitian yang dilakukan oleh Jacques Abboud, Nougarou, dan Descarreaux M pada 23 orang dewasa sehat tanpa riwayat NPB menunjukkan kelelahan otot yang digabungkan dengan perubahan bentuk jaringan tulang belakang menyebabkan peningkatan tegangan aktivitas otot, dan peningkatan distribusi aktivitas otot. Penelitian ini memberikan informasi yang menunjukkan bahwa posisi fleksi cukup lama secara berulang-ulang dapat mengubah fungsi mekanik dan neuromuskuler yang seiring waktu mengarah ke gangguan punggung bawah. ${ }^{6}$ Dalam sebuah studi observasional menunjukkan bahwa paparan posisi duduk fleksi lumbal yang maksimal hingga 15 menit dapat membuat rasa tidak nyaman yang sifatnya sementara di punggung bawah pada orang dewasa muda yang sehat tanpa adanya riwayat NPB sebelumnya. ${ }^{7}$

Berdasarkan beberapa kajian tersebut peneliti tertarik untuk mengkaji lebih lanjut hubungan lama duduk terhadap keluhan nyeri punggung bawah pada mahasiswa fakultas kedokteran Universitas Sam Ratulangi.

\section{METODE PENELITIAN}

Metode penelitian yang digunakan dalam penelitian ini adalah analitik observasional dengan pendekatan potong lintang. Populasi penelitian ini adalah mahasiswa Angkatan 2019 dan Angkatan 2020 Fakultas Kedokteran Universitas Sam Ratulangi berjumlah 304 orang. Subjek penelitian diambil menggunakan teknik simple random sampling yang berarti subjek penelitian ditentukan secara acak. Jumlah subjek penelitian ditentukan menggunakan rumus Slovin didapatkan 161 orang. Informed consent dibagikan kepada peserta lewat google formulir. Data penelitian diambil menggunakan kuesioner lewat google formulir. Kemudian, data diolah menggunakan aplikasi SPSS for Windows versi 24.0 dan hasil penelitian disajikan dalam bentuk tabel hasil penelitian. Penelitian ini menggunakan uji statistik Pearson Chi-Square.

\section{HASIL PENELITIAN}

Penyajian berdasarkan data responden yang menunjukan karakteristik subjek penelitian menurut usia (Tabel 1), jenis kelamin (Tabel 2), Indeks Massa Tubuh (IMT) (Tabel 3), rata-rata lama duduk belajar dalam sehari (Tabel 4), ada tidaknya 
keluhan nyeri punggung bawah (Tabel 5), intensitas nyeri yang dirasakan (Tabel 6), dan faktor tekanan psikologis (Tabel 7). Kemudian dilakukan uji untuk melihat ada tidaknya hubungan lama duduk terhadap keluhan nyeri punggung bawah (Tabel 8) dan ada tidaknya hubungan umur, jenis kelamin, IMT dan faktor psikologis (Tabel 9).

Tabel 1. Distribusi subjek penelitian berdasarkan usia

\begin{tabular}{ccc}
\hline $\begin{array}{c}\text { Usia } \\
\text { (Tahun) }\end{array}$ & $\begin{array}{c}\text { Frekuensi } \\
(\mathrm{n})\end{array}$ & $\begin{array}{c}\text { Persentase } \\
(\%)\end{array}$ \\
\hline 16 & 2 & 1 \\
17 & 21 & 13 \\
18 & 79 & 49 \\
19 & 46 & 29 \\
20 & 12 & 7 \\
21 & 1 & 1 \\
Total & 161 & 100 \\
\hline
\end{tabular}

Tabel 2. Distribusi subjek penelitian berdasarkan jenis kelamin

\begin{tabular}{ccc}
\hline Jenis & $\begin{array}{c}\text { Frekuensi } \\
(\mathrm{n})\end{array}$ & $\begin{array}{c}\text { Persentase } \\
(\%)\end{array}$ \\
Kelamin & 47 & 29 \\
Laki- laki & 114 & 71 \\
Perempuan & 161 & 100 \\
\hline Total & 161
\end{tabular}

Tabel 3. Distribusi subjek penelitian berdasarkan IMT

\begin{tabular}{ccc}
\hline IMT $\left(\mathrm{Kg} / \mathrm{m}^{2}\right)$ & $\begin{array}{c}\text { Frekuensi } \\
(\mathrm{n})\end{array}$ & $\begin{array}{c}\text { Persentase } \\
(\%)\end{array}$ \\
\hline Underweight & 24 & 15 \\
Normal & 89 & 55 \\
Overweight & 24 & 15 \\
Obesitas 1 & 18 & 11 \\
Obesitas 2 & 6 & 4 \\
Total & 161 & 100 \\
\hline
\end{tabular}

Tabel 4. Rata - rata lama duduk belajar dalam sehari

\begin{tabular}{ccc}
\hline $\begin{array}{c}\text { Lama } \\
\text { duduk }\end{array}$ & $\begin{array}{c}\text { Frekuensi } \\
(\mathrm{n})\end{array}$ & $\begin{array}{c}\text { Persentase } \\
(\%)\end{array}$ \\
\hline$\leq 4$ jam & 8 & 5 \\
$5-8$ jam & 95 & 59 \\
$>8$ jam & 58 & 36 \\
Total & 161 & 100 \\
\hline
\end{tabular}

Tabel 5. Keluhan Nyeri Punggung Bawah

\begin{tabular}{ccc}
\hline Keluhan NPB & $\begin{array}{c}\text { Frekuensi } \\
(\mathrm{n})\end{array}$ & $\begin{array}{c}\text { Persentase } \\
(\%)\end{array}$ \\
\hline Ya & 123 & 76 \\
Tidak & 38 & 24 \\
\hline Total & 161 & 100 \\
\hline
\end{tabular}

Tabel 6. Distribusi subjek penelitian berdasarkan intensitas nyeri NRS (Numerical Rating Scale)

\begin{tabular}{ccc}
\hline $\begin{array}{c}\text { Numerical } \\
\text { Rating Scale }\end{array}$ & $\begin{array}{c}\text { Frekuensi } \\
(\mathrm{n})\end{array}$ & $\begin{array}{c}\text { Persentase } \\
(\%)\end{array}$ \\
\hline 0 (tidak nyeri) & 38 & 24 \\
1-3 (ringan) & 57 & 35 \\
4-6 (sedang) & 59 & 37 \\
7-10 (berat) & 7 & 4 \\
\hline Total & 161 & 100 \\
\hline
\end{tabular}

Tabel 7. Distribusi menurut faktor tekanan psikologis yang berpengaruh dengan menggunakan kuesioner PSS-10 (Perceived Stress Scale-10)

\begin{tabular}{ccc}
\hline PSS-10 & $\begin{array}{c}\text { Frekuensi } \\
(\mathrm{n})\end{array}$ & $\begin{array}{c}\text { Persentase } \\
(\%)\end{array}$ \\
\hline$\leq 13$ & 23 & 14 \\
$($ Normal) & & \\
$14-26$ & 56 & 35 \\
$($ Stress $)$ & & \\
$27-40$ & 82 & 51 \\
High Stress) & & \\
\hline Total & 161 & 100 \\
\hline
\end{tabular}

\section{BAHASAN}

Pada penelitian yang dilakukan, ditemukan nilai $\mathrm{p}<0,05$ lewat hasil analisis sehingga peneliti menyimpulkan bahwa $\mathrm{H} 0$ ditolak yaitu terdapat hubungan antara lama duduk terhadap Keluhan Nyeri Punggung Bawah. Penelitian ini sama halnya dengan penelitian yang dilakukan pada operator komputer perusahaan travel di Manado yang memperlihatkan korelasi yang kuat menggunakan uji alternatif Fisher exact (p $=0,014$ ) dan paling banyak ditemukan pada pekerja dengan lama duduk 7-8 jam sehari dan nyeri bersifat sedang dengan derajat nyeri 4-6 menggunakan Numerical Rating Scale (NRS). ${ }^{8}$ 
Tabel 8. Hubungan Lama Duduk terhadap Keluhan Nyeri Punggung Bawah

\begin{tabular}{ccccccccc}
\hline & & \multicolumn{6}{c}{ Keluhan Nyeri Punggung Bawah } & \multirow{2}{*}{ P Value } \\
\cline { 3 - 7 } Variabel & \multirow{2}{*}{ Kategori } & \multicolumn{3}{c}{ Ya } & \multicolumn{3}{c}{ Tidak } & \multicolumn{3}{c}{ Total } & \\
\cline { 3 - 8 } & & $\mathrm{n}$ & $\%$ & $\mathrm{n}$ & $\%$ & $\mathrm{n}$ & $\%$ & \\
\hline \multirow{2}{*}{ Lama } & $1-4$ jam & 2 & 1 & 6 & 4 & 8 & 5 & \\
Duduk & $5-8$ jam & 69 & 43 & 26 & 16 & 95 & 59 & 0,001 \\
& $>8$ jam & 52 & 32 & 6 & 4 & 58 & 36 & \\
\hline
\end{tabular}

*Hasil uji Chi Square, dapat disimpulkan terdapat hubungan bermakna antara lama duduk terhadap nyeri punggung bawah pada mahasiswa kedokteran Universitas Sam Ratulangi.

Tabel 9. Hubungan Umur, Jenis Kelamin, IMT, dan Faktor Psikologis terhadap Keluhan Nyeri Punggung Bawah

\begin{tabular}{|c|c|c|c|c|c|c|c|c|}
\hline \multirow{3}{*}{ Variabel } & \multirow{3}{*}{ Kategori } & \multicolumn{6}{|c|}{ Keluhan Nyeri Punggung Bawah } & \multirow{3}{*}{$\mathrm{P}$ Value } \\
\hline & & \multicolumn{2}{|c|}{$\mathrm{Ya}$} & \multicolumn{2}{|c|}{ Tidak } & \multicolumn{2}{|c|}{ Total } & \\
\hline & & $\mathrm{n}$ & $\%$ & $\mathrm{n}$ & $\%$ & $\mathrm{n}$ & $\%$ & \\
\hline \multirow{6}{*}{ Umur } & 16 Tahun & 2 & 1 & 0 & 0 & 2 & 1 & \multirow{6}{*}{0,406} \\
\hline & 17 Tahun & 19 & 12 & 2 & 1 & 21 & 13 & \\
\hline & 18 Tahun & 61 & 38 & 18 & 11 & 79 & 49 & \\
\hline & 19 Tahun & 32 & 20 & 14 & 9 & 46 & 29 & \\
\hline & 20 Tahun & 8 & 5 & 4 & 2 & 12 & 7 & \\
\hline & 21 Tahun & 1 & 1 & 0 & 0 & 1 & 1 & \\
\hline \multirow{2}{*}{$\begin{array}{c}\text { Jenis } \\
\text { Kelamin }\end{array}$} & Laki-laki & 34 & 21 & 13 & 8 & 47 & 29 & \multirow[b]{2}{*}{0,436} \\
\hline & Perempuan & 89 & 55 & 25 & 16 & 114 & 71 & \\
\hline \multirow{5}{*}{ IMT } & Underweight & 19 & 12 & 5 & 3 & 24 & 15 & \multirow{5}{*}{0,907} \\
\hline & Normal & 66 & 41 & 23 & 14 & 89 & 55 & \\
\hline & Overweight & 18 & 11 & 6 & 4 & 24 & 15 & \\
\hline & Obese 1 & 15 & 9 & 3 & 2 & 18 & 11 & \\
\hline & Obese 2 & 5 & 3 & 1 & 1 & 6 & 4 & \\
\hline \multirow{3}{*}{ PSS-10 } & Normal & 13 & 8 & 10 & 6 & 23 & 14 & \multirow{3}{*}{0,045} \\
\hline & Stress & 46 & 29 & 10 & 6 & 56 & 35 & \\
\hline & High Stress & 64 & 40 & 18 & 11 & 82 & 51 & \\
\hline
\end{tabular}

*Hasil uji Chi Square dapat disimpulkan (1) tidak ada hubungan antara umur seseorang dengan keluhan nyeri punggung bawah, (2) tidak ada hubungan antara jenis kelamin seseorang dengan keluhan nyeri punggung bawah, (3) tidak ada hubungan antara IMT dengan keluhan nyeri punggung bawah, dan (4) terdapat hubungan antara faktor psikologis dengan keluhan nyeri punggung bawah.

Duduk dengan lama 8 jam perhari merupakan faktor resiko terhadap nyeri punggung bawah. Hal ini terkait dengan nyeri punggung dan kelelahan otot. Duduk menggunakan komputer ketika belajar atau bekerja dalam waktu 2-4 jam cukup menimbulkan rasa tidak nyaman pada daerah punggung bawah. Penelitian yang dilakukan pada mahasiswa kedokteran dan mahasiswa keperawatan di Pakistan menyatakan duduk \pm 2 jam ketika belajar berdampak pada rasa tidak nyaman yang dirasakan pada punggung bawah. ${ }^{9}$ Rasa tidak nyaman ini dapat terjadi akibat duduk dalam waktu yang lama dan posisi duduk yang tidak tepat. Saat duduk, tubuh akan memberikan beban yang dipengaruhi gaya gravitasi dan akan menimbulkan gaya tekanan yang berlawanan arah sama besarnya. Paparan dari tekanan tersebut mempengaruhi kondisi fisik yang berdampak pada kerusakan suatu sistem pada tulang belakang. Penelitian mengatakan posisi duduk yang lama tanpa adanya sandaran beresiko lebih besar mengalami nyeri punggung bawah karena tekanan pada 
diskus intervertebratalis akan lebih besar ketika duduk fleksi. Penelitian yang sama juga ditunjukan pada mahasiswa kedokteran di Delhi, terdapat hasil yang signifikan terjadi pada mahasiswa yang belajar dengan posisi yang tidak tepat dengan duduk yang lama. ${ }^{10}$ Faktor risiko keluhan muskuloskeletal dalam hal ini bisa terjadi karena gaya tekanan, postur tubuh, pengulangan dan durasi kerja.

Dalam penelitian ini tidak ditemukan hubungan bermakna antara umur dengan keluhan nyeri punggung bawah. Penelitian yang sama yang dilakukan pada mahasiswa kedokteran di Paris yaitu tidak ditemukan hubungan bermakna antara keluhan nyeri punggung bawah dengan pertambahan usia. Pada penelitian ini juga tidak ditemukan hubungan bermakna antara jenis kelamin dengan keluhan nyeri punggung bawah. Hasil untuk jenis kelamin yang menyatakan tidak ada hubungan antara jenis kelamin seseorang dengan keluhan nyeri punggung bawah. Hal ini tampak berbeda dengan penelitian pada mahasiswa kedokteran di Paris yang menunjukkan hasil signifikan dengan prevalensi nyeri punggung tampaknya lebih tinggi di antara perempuan dibandingkan laki-laki. ${ }^{11}$ Peneliti menemukan hasil yang berbeda karena jumlah sampel perempuan dan laki-laki pada penelitian ini tidak seimbang sehingga tidak menunjukkan hasil yang signifikan. Hasil yang menyatakan tidak ada hubungan antara IMT dengan keluhan nyeri punggung bawah menunjukkan hal yang berbeda dengan penelitian yang dilakukan pada mahasiswa kedokteran di Malaysia yang menemukan hubungan antara IMT dan keluhan nyeri punggung bawah. ${ }^{12}$

Pada penelitian ini menemukan hubungan antara faktor psikologis dengan keluhan nyeri punggung bawah. Faktor psikologis dikaitkan dengan stress yang memengaruhi kelelahan pada otot dan juga membuat beban kerja lebih berat. Penelitian ini sama halnya dengan penelitian pada mahasiswa kedokteran Serbia yang memperlihatkan hasil bermakna memiliki stress mendekati ujian. ${ }^{13}$

\section{SIMPULAN}

Terdapat hubungan lama duduk terhadap keluhan nyeri punggung bawah pada mahasiswa fakultas kedokteran Universitas Sam Ratulangi.

\section{Konflik Kepentingan}

Penulis menyatakan tidak terdapat konflik kepentingan dalam studi ini.

\section{DAFTAR PUSTAKA}

1. Wong AYL, Chan TPM, Chau AWM, Tung Cheung H, Kwan KCK, Lam $\mathrm{AKH}$, et al. Do different sitting postures affect spinal biomechanics of asymptomatic individuals? GaitPosture. 2019;67 (May 2018):230-5.

2. Daneshmandi H, Choobineh A, Ghaem H, Karimi M. Lifestyle Adverse Effects of Prolonged Sitting Behavior on the General Health of Office Workers. 2017;7(2):69-75.

3. Kikuchi $H$, Inoue $S$, Odagiri $Y$, Inoue $M$, Sawada N, Tsugane S. Occupational sitting time and risk of all-cause mortality among Japanese workers workers. 2015; 41(6):519-28.

4. Wu A, March L, Zheng X, Huang J, Wang X, Zhao J, et al. Global low back pain prevalence and years lived with disability from 1990 to 2017: estimates from the Global Burden of Disease Study 2017. 2020;8(6).

5. Kwon Y, Kim J, Heo J, Jeon H, Choi E. The effect of sitting posture on the loads at cervico-thoracic and lumbosacral joints. 2018;26:40918.

6. Abboud J, Nougarou F, Descarreaux M. Muscle activity adaptations to spinal tissue creep in the presence of muscle fatigue. PLoS One. 2016;11(2):1-14.

7. Petersson M, Abbott A. lumbar sitting posture: An observational study. 2020;11(3):158-66.

8. Sari NPLNI, Mogi TI, Angliadi E. Hubungan Lama Duduk Dengan 
Kejadian Low Back Pain Pada Operator Komputer Perusahaan Travel Di Manado. e-CliniC. 2015;3(2).

9. Hafeez K, Ahmed Memon A, Jawaid M, Usman S, Usman S, Haroon S. Back pain - are health care undergraduates at risk? Iran J Public Health. 2013;42(8):819-25.

10. Aggarwal N, Anand T, Kishore J, Ingle GK. Low back pain and associated risk factors among undergraduate students of a medical college in Delhi. Educ Heal Chang Learn Pract. 2013;26(2):103-8.

11. Amelot A, Mathon B, Haddad R, Renault MC, Duguet A, Steichen O. Low Back Pain among Medical
Students: A Burden and an Impact to Consider!. Spine 2019;44(19): 1390-5.

12. Alshagga MA, Nimer AR, Yan LP, Ibrahim IAA, Al-Ghamdi SS, Radman Al-Dubai SA. Prevalence and factors associated with neck, shoulder and low back pains among medical students in a Malaysian Medical College. BMC Res Notes. 2013;6(1).

13. Vujcic I, Stojilovic N, Dubljanin E, Ladjevic N, Ladjevic I, SipeticGrujicic S. Low Back Pain among Medical Students in Belgrade (Serbia): A Cross-Sectional Study. Pain Res Manag. 2018; Volume 2018, Article ID 8317906, 6 pages 